\title{
Plant community development in the first growing season of a created mitigation wetland bank as influenced by design elements
}

\author{
Changwoo Ahn* \\ Department of Environmental Science and Policy, George Mason University, Fairfax, VA 22030, USA
}

\begin{abstract}
Vegetative communities of created wetlands often display lower species richness, less cover, higher occurrence of non-native or invasive species, and fewer obligate wetlands species than those in natural wetlands, thus failing to meet basic success criteria for wetland mitigation. This study examined the effects of two design elements, disking-induced microtopography and hydrologic regime, on the first year vegetation development pattern of a mitigation wetland newly created in the Virginia piedmont. Elevation and species cover were measured along replicate multiscale circular transects in two adjacent wetland sites that are different in their hydrologic regime. Two microtopographic indices, tortuosity (T) and limiting elevation difference (LD), were calculated from the elevation measurements. Both indices were higher in disked plots than non-disked plots, showing the effect of disking on microtopography. Out of forty-one vegetation taxa observed in the wetland, 29 taxa were naturally colonized and 12 taxa were seeded. All plots except one non-disked plot were dominated by wetland vegetation. Species richness and diversity were higher in disked than in non-disked plots. Vegetation community development seemed also influenced significantly by hydrologic regime of the site. The effect of microtopography on species richness and diversity was more pronounced in a relatively dry site compared to a wet site. In addition, percent cover, species richness and diversity of vegetation were positively correlated with microtopographic indices such as $\mathrm{T}$ and LD. Two design elements, microtopography and hydrologic regime, should be considered and incorporated in wetland creation to enhance plant community development.
\end{abstract}

Key words: created wetlands, disking, hydrologic regime, microtopography, plant diversity, Virginia piedmont, wetland mitigation

\section{INTRODUCTION}

Wetlands are often created as compensatory mitigation under Section 404 of Clean Water Act in the United States (National Research Council 2001), but created wetlands may initially lack structural diversity and often fail to support biotic communities comparable to those in similar, naturally occurring wetlands (Zedler and Callaway 1999, Campbell et al. 2002, Spieles 2005). Vegetation attributes such as percent cover, species identity, species richness, and wetland indicator status have been used as a measure of mitigation success in most post-construc- tion monitoring of created mitigation wetlands (Breaux and Serefiddin 1999, Spieles 2005). Early vegetation establishment can have profound implications on the development of the structure and function of created mitigation wetlands (Atkinson et al. 2005, Spieles 2005), as the vegetation community influences the biogeochemical functions expected to develop, such as primary productivity, soil development, and nutrient retention. Wetland mitigation success thus often relies on the early establishment and development of the wetland vegetation

Received 16 July 2010, Accepted 06 September 2010

*Corresponding Author

E-mail: cahn@gmu.edu

Tel: +1-703-993-3978 cc This is an Open Access article distributed under the terms of the ativecommons.org/licenses/by-nc/3.0/) which permits unrestricted non-commercial use, distribution, and reproduction in any medium, provided the original work is properly cited. 
community. However, vegetation in created wetlands often displays lower species richness, less cover, higher occurrence of non-native or invasive species, and fewer obligate wetlands species than that of natural wetlands (Galatowitsch and van der Valk 1996, Zedler and Callaway 1999, Campbell et al. 2002, Spieles 2005). Thus, identifying wetland creation methods that would enhance the development of a diverse wetland plant community may increase the likelihood of mitigation success.

Microtopography is especially important in wetlands, where $<5 \mathrm{~cm}$ of variation in elevation can shift hydrologic conditions experienced by individual plant species (Vivian-Smith 1997, Werner and Zedler 2002, Peach and Zedler 2006, Moser et al. 2007). At low water level conditions, microhighs may be exposed to aerobic conditions while microlows and flats are still under water in anaerobic conditions, creating ecological niches or a mosaic of microenvironments that vary in abiotic and biotic conditions. These microenvironments are known to influence seed germination, seedling establishment, and seedling growth, critical phases in the life cycle of plants (Smith and Capelle 1992, Schupp 1995, Moser et al. 2007). Microenvironments also facilitate or inhibit plant species distribution by influencing resource heterogeneity (Baer et al. 2005), interspecific differences in habitat preferences (Vivian-Smith 1997), and differential mortality and growth rates at different microtopographic positions (Jerling 1981, Hamrick and Lee 1987). Created mitigation wetlands often lack microtopography due to use of heavy machinery for grading during the construction process (Whittecar and Daniels 1999, Stolt et al. 2000). Grading is usually performed to assure surface variation within a centimeter or two of the site plan elevation, so the microtopographic variability more typical of natural settings is eliminated or significantly reduced (Stolt et al. 2000).

The hydrologic regime can play a major role in the distribution and abundance of wetland plants (Cronk and Fennessy 2001). The flooded areas of wetlands support flood tolerant species (van der Valk 1981, Bruland and Richardson 2005), although these areas support fewer species in general (Bruland and Richardson 2005). On the other hand, exposed (non-flooded) soils characterized by moist conditions can facilitate seed germination (van der Valk and Davis 1978, Ahn et al. 2004) and seedling growth of a variety of wetland species (Cronk and Fennessy 2001). Effects of temporal and spatial variability of soil moisture or water table depth on wetland plant structure and composition have been extensively studied (Titus 1990, Vivian-Smith 1997, Bruland and Richardson 2005, Dwire et al. 2006). Wetlands characterized by topo- graphic variability would include both flooded and nonflooded areas with varying moisture levels or water table depths, supporting a wide variety of wetland species and influencing plant community composition and distribution.

The goal of the study is to investigate the effects of two design elements, hydrologic and microtopographic, on the first year vegetation community development in a created mitigation wetland. Little is known about the effects of design elements such as hydrologic regime and microtopography on the early development of plant community in created mitigation wetlands. The outcome of the study will be informative to wetland engineers and managers in wetland creation practices. The objectives of the study were to evaluate vegetation attributes (e.g., species richness, diversity, plant cover, floristic quality, and wetland indicator status) as affected by (a) presence/ absence of disking-induced microtopography, and (b) by different hydrologic regime (i.e., dry vs. wet) in a newly created mitigation wetland.

\section{MATERILAS AND METHODS}

\section{Site description}

The study was performed in Loudoun County mitigation wetland (LC) $\left(39^{\circ} 02.05^{\prime} \mathrm{N}, 77^{\circ} 36.5^{\prime} \mathrm{W}\right)$, a 32 -acre wetland mitigation bank newly created in the northern Piedmont region of Virginia, during the summer of 2007. LC was constructed during July through August in 2006 by Wetland Studies and Solutions, Inc. (WSSI; Gainesville, VA, USA) and is located in the 100 year floodplain of Goose Creek and its tributary Big Branch. The wetland design includes $0.2 \mathrm{~m}$ topsoil atop a $0.3 \mathrm{~m}$ or thicker low permeability $\left(1 \times 10^{-7} / \mathrm{ms}\right)$ subsoil layer, resulting in a perched water table that fluctuates with precipitation. Groundwater exchange was negligible. The LC wetland consists of two contiguous sites (i.e., LC1 and LC2) separated by a berm with a drainage channel. LC1 was approximately $0.4 \mathrm{~m}$ higher in position than LC2 (Fig. 1). This design causes LC1 to drain quickly leaving it inundated only for very short periods during and after precipitation, while LC2 remains under standing water (i.e., $<12 \mathrm{~cm}$ ) for several months. With the difference in hydrologic regime, we categorized LC1 as a dry site and LC2 as a wet site. Both sites were hydro-seeded in the summer of 2006 with commercially available wetland plant seed mix of 26 herbaceous plant species (at the rate of $1.5 \mathrm{~g} / \mathrm{m}^{2}$ ) appropriate for the region and the intended hydrology 


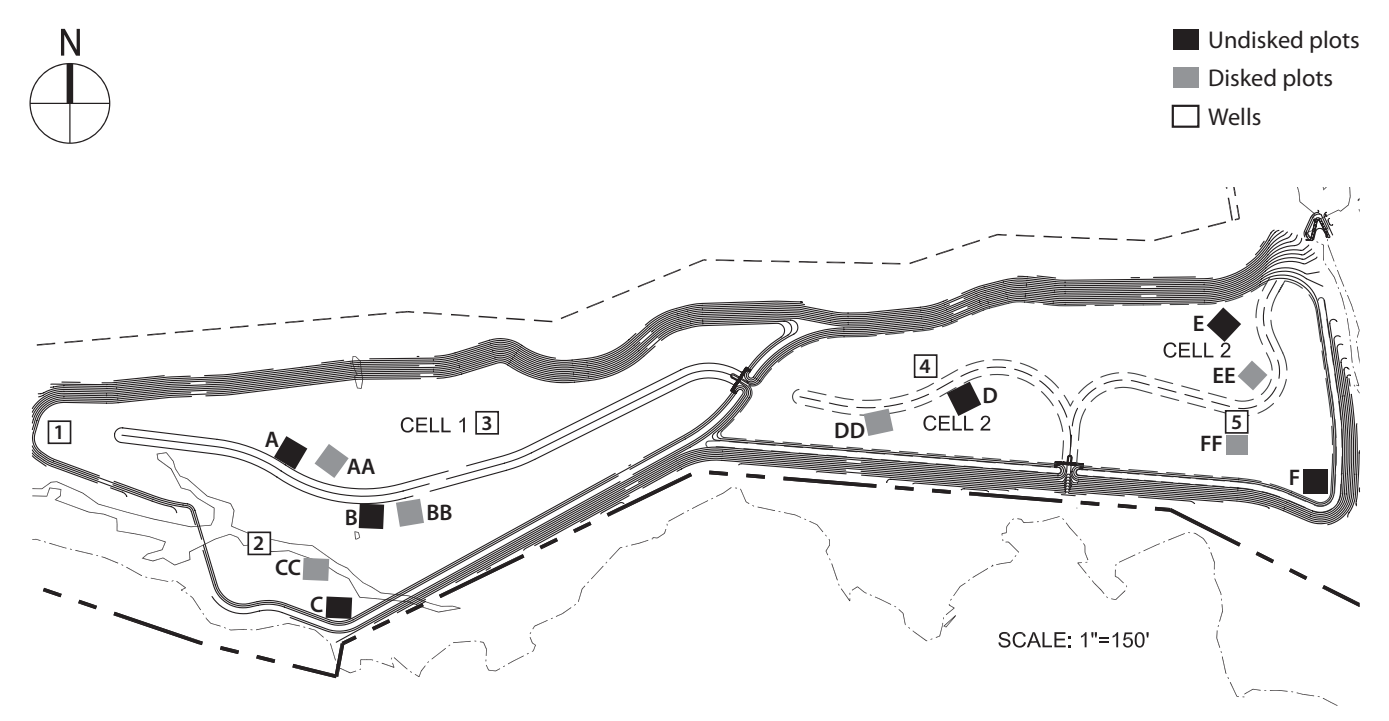

Fig. 1. Permanent plots locations for microtopography study at Loudoun County Mitigation Bank (LC). There are two cells in the wetland (i.e., LC 1 and LC 2) with six undisked plots labeled with single letters (A-F) and six disked plots labeled with double letters (AA-FF). The figure also shows five wells installed to study the hydrologic regime of $L C$.

(e.g., wetland meadow as opposed to obligate wetland). Although the created wetlands are intended to mitigate the loss of palustrine forested wetlands, all trees planted in December, 2006 were still small saplings during our first-growing season vegetation study, so these wetlands can best be characterized as palustrine emergent.

\section{Study plot design}

Twelve $10 \mathrm{~m} \times 10 \mathrm{~m}$ plots were randomly staked out in LC - six in LC1 (i.e., A, AA, B, BB, C, CC) and another six in LC2 (D, DD, E, EE, F, FF). Three plots in each site were kept non-disked (i.e., single-lettered plot) while the rest of the wetland area was disked (i.e. double-lettered plots) during the construction. Each disked plot was adjacent to the non-disked plot to reduce variability in other environmental factors. At each plot, a set of 4 tangentially-conjoined circular transects (Moser et al. 2007) was placed randomly in a nested design; however, transects were always laid out in north-south direction with first reading $(0 \mathrm{~cm})$ at the southernmost extent of the transect to maintain consistency. The diameter of the smallest transect was $0.5 \mathrm{~m}$, determined by assuming that the smallest zone of influence of microtopographic variation on plant species is within $0.5 \mathrm{~m}$. Successive diameters of each transect were determined by doubling the previous diameter $-1 \mathrm{~m}, 2 \mathrm{~m}$, and $4 \mathrm{~m}$, to address the effect of spatial scale of microtopography measurements.

\section{Hydrologic regime}

Precipitation data were obtained from the weather station at Dulles International Airport. The Palmer Drought Severity Index (i.e., D0 to D2) (Heddinghause and Sabol 1991) was used to characterize precipitation conditions during the study period. In each site, the depth to water table was monitored using a $70 \mathrm{~cm}$ slotted well constructed of $3.18 \mathrm{~cm}\left(=1 \frac{1 / 4}{4}\right)$ polyvinyl chloride pipe. Three wells were installed in LC1 and two in LC2 initially by the builder as part of their legal, post-construction monitoring (Fig. 1). Water table depth was measured weekly ( $N=20$ per site) from before (early March) to late in the growing season (early October), and used to calculate the average water table level in each site. To further characterize hydrologic condition of individual study plots without disturbing the surrounding microtopography, soil moisture content was measured in the late growing season for the top $10 \mathrm{~cm}$ of soil. Soil cores were taken using a $1.8 \mathrm{~cm}$-diameter soil auger from each plot, directly within the set of circular transects. Sub-samples were oven-dried at $105^{\circ} \mathrm{C}$ for $48 \mathrm{~h}$ and used to determine moisture content for each sample (calculated as [wet weight - dry weight]/dry weight, expressed as a percentage). The average of percent soil moisture content of plots $(N=6$ per site) was also used as the measure of moisture experienced by plants within each site. 


\section{Microtopography measures}

Field measurement of microtopography consisted of elevation measurements taken using surveying equipment (Sokkia SET4110 total station) in the study plots of each site. Measurements were taken at $10 \mathrm{~cm}$ intervals along the $0.5 \mathrm{~m}(N=16), 1 \mathrm{~m}(N=32)$, and $2 \mathrm{~m}(N=63)$ diameter circular transect paths, and at $20 \mathrm{~cm}$ intervals along the $4 \mathrm{~m}(N=63)$ diameter circular transect path. Measurement intervals were chosen as appropriate to the scale of interest (plant-scale), the equipment used (survey rod base diameter of $6 \mathrm{~cm}$ ), and the transect sizes. Conditions for surveying were generally dry (with soil yielding minimally underfoot), although care was taken not to alter the existing microtopography during elevation measurement. Elevation data were recorded to the nearest millimeter.

Using transect elevations, tortuosity ( $\mathrm{T}$, unitless) (Kamphorst et al. 2000) - a measure of surface roughness - and limiting elevation difference (LD, cm) (Linden and Van Doren 1986) - a measure of surface relief - were calculated to quantify microtopography for each transect as described in Moser et al. (2007). Because the size of the individual transect differed, the lag intervals used for each scale was different: for the $0.5 \mathrm{~m}$-diameter transects, eight lag intervals $(10-80 \mathrm{~cm})$ as measured along the transect were used for analysis; for $1 \mathrm{~m}$-diameter transects, fifteen lag intervals $(10-150 \mathrm{~cm})$ were analyzed; for $2 \mathrm{~m}$-diameter transects, twenty lag distances (10-100 $\mathrm{cm})$ were analyzed; and for $4 \mathrm{~m}$-diameter transects, fifteen lag intervals $(20-300 \mathrm{~cm})$ were analyzed.

\section{Vegetation}

Species identity and percent cover of all herbaceous vegetation were recorded along each circular transect using $0.2 \mathrm{~m}^{2}$ circular quadrat. Vegetation data were collected at $80 \mathrm{~cm}$ intervals along the $0.5 \mathrm{~m}(N=2), 1 \mathrm{~m}(N$ $=3)$, and $2 \mathrm{~m}(N=8)$ diameter circular transect paths, and at $160 \mathrm{~cm}$ intervals along the $4 \mathrm{~m}(\mathrm{n}=8)$ diameter circular transect path $(N=21)$. Species were field-identified (Tiner 1988) and percent cover visually estimated, with a minimum cover percentage of 1 percent. Visual estimates of less than $15 \%$ cover were reported in increments of $1 \%$, while those of $15 \%$ or more were reported in $5 \%$ increments. Cover was also estimated for non-plant surface features, such as large rocks or logs. Due to multiple herbaceous canopy layers, the sum of species cover estimates could exceed $100 \%$, even when visual estimate of total cover was less than $100 \%$. Species were assigned a wetland indicator category (Reed 1988, Pepin 2000). Plant species were separated into four categories: overall (i.e., total), seeded, volunteer, and invasive species.

Species richness of each category per plot was determined from the number of species of each category that were recorded in each plot. Species richness per $\mathrm{m}^{2}$ for each plot was estimated using taxon-sampling curves to derive $S$ for $N=5$ quadrats using EstimateS (Colwell 2006), based on the mean for 50 randomized runs without replacement. To correct for differences in sampling intensity among transects, rarefied estimate of species richness per transect was calculated based on the number of quadrats $(N=2)$ for the smallest transect $(0.5 \mathrm{~m})$ (Colwell 2006). Shannon diversity, $H^{\prime}\left(H^{\prime}=\Sigma p_{i} \ln p_{i}\right.$, where $\mathrm{p}_{\mathrm{i}}$ represents the relative contribution of each species to total percent cover), was used to characterize plant diversity. Both plot-level and transect-level diversity were calculated using EstimateS (Colwell 2006).

Vegetation plots were assigned a wetland prevalence index (P. I.) value according to the weighted average of indicator ranks, excluding unidentified and non-listed species (Wentworth et al. 1988). The P. I. was calculated as P. I. $=\sum \mathrm{W}_{\mathrm{i}} \mathrm{A}_{\mathrm{i}} / \sum \mathrm{A}_{\mathrm{i}}$, where, $\mathrm{W}_{\mathrm{i}}$ is wetland indicator category index value for species $I, A_{i}$ is relative cover estimate for species $i$, and $i$ is individual species (Wentworth et al. 1988). The calculation was based on species regional wetland indicator category (Reed 1988) and relative cover of each species in $0.2 \mathrm{~m}^{2}$ plots. Wetland indicator index values for each species were derived from the regional indicator categories and rank from 1 to 5 as follows: $1=$ obligate wetland, 2 = facultative wetland (FACW), 3 = facultative (FAC), 4 = facultative upland (FACU), 5 = upland (UPL) (Wentworth 1988).

\section{Data analyses}

Differences between LC1 and LC2 in water table depths were examined by performing a Mann-Whitney U-test because of the non-normality in the data that did not respond to transformation. Effects of disking (disked vs. non-disked) and scale $(0.5 \mathrm{~m}, 1 \mathrm{~m}, 2 \mathrm{~m}$, or $4 \mathrm{~m})$ on microtopographic indices ( $\mathrm{LD}$ and $\mathrm{T}$ ) were analyzed by using two-way multivariate analysis of variance (MANOVA). When two-way MANOVA revealed significant disking and scale effects, ANOVA was used for each response variable. Further, when ANOVA revealed significant scale effect, Fisher's least significant difference (LSD) test was used for multiple comparisons of means. The effects of disking, scale, and hydrologic regime on the percent cover (overall, seeded, and volunteer taxa), species richness 
(overall, seeded, and volunteer taxa), $\mathrm{H}^{\prime}$ (overall, seeded, and volunteer taxa), and P. I. of overall taxa were analyzed using three-way MANOVA, then separately using ANOVA for each of the response variables when threeway MANOVA revealed significant effects. MANOVA analyses were conducted using Type IV sum-of-squares and an alpha level of 0.05 (due to unequal sample sizes, Pillai's Trace was adopted as a more robust alternative to Wilks' L). Vegetation data were tested for normality and homogeneity of variance, and to meet parametric assumptions appropriate transformations were applied as follows: square root (percent cover, species richness of overall taxa, and Shannon's diversity of volunteer taxa), natural log (LD species richness of volunteer taxa), natural $\log (\mathrm{x}+1)$ (species richness of seeded taxa and $\mathrm{H}^{\prime}$ of overall taxa), and square root ( $\mathrm{k}-\mathrm{x})$, where $\mathrm{k}$ is constant from which each score is subtracted so that the smallest score is 1 (P. I.) (Tabachnick and Fidell 2001). For transformed variables, mean values are reported in original untransformed units in results. The relationship between microtopographic indices and vegetation variables were examined by performing Pearson correlation analyses. All statistical analyses were performed using SPSS ver. 15.0 (SPSS 2006).

Within-plot similarity and between-plot dissimilarity and the contributions of individual species to similarity/ dissimilarity of each plant category were examined by performing decomposition of the Bray-Curtis similarity used for ANOSIM using PRIMER (PRIMER-E Ltd. 2006).

\section{RESULTS AND DISCUSSION}

\section{Hydrologic regime}

There were five shallow wells in total for water table depth monitoring in LC, three in LC1 and two in LC2, fairly close to the study plots, both non-disked and disked that were literally side by side. Mean water table depths in two LC sites were fairly different in the hydrologic regime (Fig. 2). Overall, the water table depth of LCl (i.e. dry site) was significantly lower than that of LC2 (i.e. wet site) (Mann-Whitney, $U=84, P<0.001$ ) (Fig. 2). The mean water table depths for LC1 and LC2 during the growing season were $-19.04 \pm 4.6 \mathrm{~cm}$ and $-6.08 \pm 3.5 \mathrm{~cm}$ (mean \pm standard error), respectively. During the early growing season both dry and wet sites remained slightly inundated with standing water being comparable to each other, however the water table depth in LC1 gradually declined after that period, whereas the water table level in LC2 was

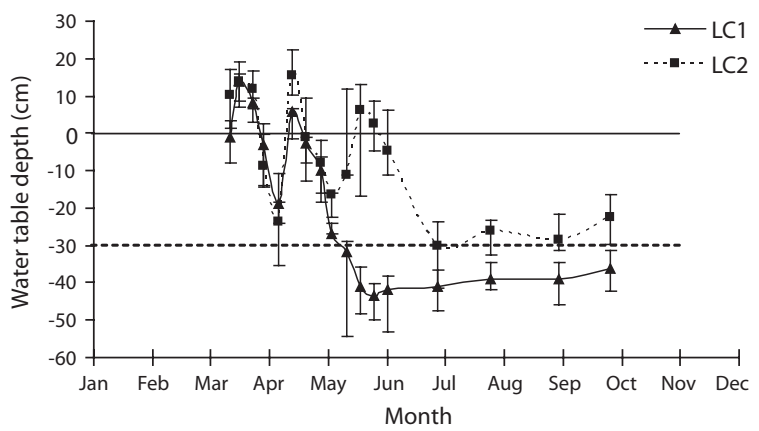

Fig. 2. Mean water table depths ( \pm standard error) of two sites, LC1 (dry) and LC2 (wet), in Loudoun County mitigation wetland during the growing season of 2007 . The solid line represents ground surface. The dashed line represents $30 \mathrm{~cm}$ below the ground surface, the depth at and above which saturation to the surface is required in Virginia for a consecutive number of days for at least 12.5 percent of the growing season to satisfy the wetland hydrology criterion.

above or near the surface until mid-June (Fig. 2). For rest of the growing season, the water table depths were well below the surface, exposing soils in both sites. The water table depth of LCl remained fairly at and above $30 \mathrm{~cm}$ below the surface whereas that of LC2 remained mostly under $30 \mathrm{~cm}$ below the surface (Fig. 2). Although different in the hydrologic regime both LC1 and LC2 met the duration criterion for wetland hydrology (i.e., saturation or inundation within $30 \mathrm{~cm}$ of the soil surface for a consecutive number of days for at least 12.5 percent of the growing season ( $\sim 30$ days) (Federal Interagency Committee for Wetland Delineation 1989).

Soil moisture content (\%) showed the same pattern between the two sites with the dry LCl $(9 \pm 0.9)$ was significantly lower than that of LC2 $(21 \pm 2.9)$. However, no significant difference in soil moisture was found between disked and non-disked plots either in LC1 (disked $=8.3 \pm$ 1.0 , non-disked $=9.1 \pm 1.6$ ) or in LC2 (disked mean $=20.5$ \pm 5.6 , non-disked mean $=21.5 \pm 6.1$ ). Previous studies suggested that microtopography induced by disking creates the prevalence of inundated/saturated conditions that would better support native wetland plant communities (Tweedy et al. 2001, Moser et al. 2007), which was not observed in our study. This may be due to the drought conditions experienced in the study area in 2007. Precipitation data obtained from the Dulles International Airport (Loudoun County, VA) during the period January 1-August 21, 2007 was 9.53 inches below normal. Only the month of April recorded precipitation data above the normal monthly precipitation, but only 0.16 inches above normal. Most of the growing season was under drought conditions in 2007 (National Drought Mitigation Center 2008). Drought severity was measured as D0 (i.e., 
abnormally dry) or D1 (i.e., moderately dry) mostly from May through October with a couple of D2 (severely dry) by National Drought Mitigation Center (2008).

\section{Microtopography}

Microtopographic indices ranged from 1.001 to 1.024 for $\mathrm{T}$ and 0.362 to $3.765 \mathrm{~cm}$ for $\mathrm{LD}$ (Table 1). Results of MANOVA indicated that the effects of both disking and scale on the combined dependent variable of $\mathrm{T}$ and $\mathrm{LD}$ were significant (Disking: Pillai's Trace $=0.480, F_{2,38}=$ 17.53, $P<0.001$; Scale: Pillai's Trace $=0.879, F_{6,78}=0.194$, $P<0.001$ ) with no significant interaction between disking and transect scale (Pillai's Trace $=0.054, F_{6,78}=0.362$, $P=0.901$ ). One-way ANOVA was followed to test if $\mathrm{T}$ and LD were different by transect scale. $T$ was significantly higher in disked plots than that in non-disked plots $\left(F_{1,}\right.$ ${ }_{39}=13.240, P=0.004$ ) (Fig. 3a). Fisher's LSD tests showed that there was significant difference in T $\left(F_{3,19}=4.000, P=\right.$ 0.023 ) among scales in disked plots. Ts of $1 \mathrm{~m}$ transect and $2 \mathrm{~m}$ transect were significantly higher than that of $4 \mathrm{~m}$ transect in disked plots (Fig. 3a). There was no difference of $\mathrm{T}$ across transect scale of measurement in non-disked plots $\left(F_{3,20}=1.470, P=0.253\right.$ ) (Fig. 3a). LD was nearly two times higher in disked plots than in non-disked plots $\left(F_{l,}\right.$ ${ }_{39}=35.54, P<0.001$ ) (Fig. 3b). Fisher's LSD tests indicated that there were significant differences in LDs by scale in both non-disked $\left(F_{3,20}=5.691, P=0.006\right)$ and disked plots $\left(F_{3,19}=7.519, P=0.002\right)$. LDs of $1 \mathrm{~m}, 2 \mathrm{~m}$, and $4 \mathrm{~m}$ transects were significantly higher than that of $0.5 \mathrm{~m}$ transect, and $\mathrm{LD}$ of $1 \mathrm{~m}$ transect was significantly lower than that of $4 \mathrm{~m}$ transect in disked plots (Fig. 3b). LDs of $2 \mathrm{~m}$ and $4 \mathrm{~m}$ transects were significantly higher than that of $0.5 \mathrm{~m}$ transect in non-disked plots.

The microtopography of disked plots was higher than that of non-disked plots in terms of both T and LD, clearly showing the effect of disking in inducing microtopographic variation. There was greater distinction of LD between disked and non-disked plots as compared to that of T (Fig. 3a and 3b), suggesting that surface relief is more likely responsible for difference in microtopography between disked and non-disked plots than surface roughness. The range of values obtained for tortuosity (surface roughness) was within the range obtained by previous studies (1.00-1.02) (Werner and Zedler 2002, Moser et al. 2007). However, the range of $\mathrm{LD}$ values $(0.36-3.77 \mathrm{~cm})$ calculated in our study were relatively small being comparable to that $(0.4-12.4 \mathrm{~cm})$ of a previous study conducted in created wetlands with varying ages (i.e., 1-6 yrs old) in the Virginia piedmont (Moser et al. 2007).
Microtopography measured at different transect scales used drastic difference between the transect scales or specific patterns along the scale of transect in this study. Based on the resolution used in our measurement, wetland microtopography seemed to differ only minimally from extents of $0.5-4 \mathrm{~m}$, a result similar to that of Morzaria-Luna et al. (2004)

\section{Vegetation}

\section{Species richness and percent cover}

A total of 41 plant taxa (with 40 identified to species and 1 identified to genus) (Table 2) was observed in the newly created wetland during the first growing season. Overall, there were 29 volunteer species originally not included in the seed mix, and 12 seeded taxa found (Table 2). This number of volunteers indicates a high rate of natural seed dispersal into, and germination/survival within the study sites. A total of 40 species were found in disked plots whereas 28 taxa were found in non-disked plots (Tables 2 and 3). More seeded and volunteer taxa were present consistently in disked plots than in non-disked plots, showing a significantly positive effect of disking on species richness (Tables 3 and 4). There was significant difference in species richness also by hydrologic regime (i.e., dry LC1 vs. wet LC2) (Table 2). Of the total taxa, 34 were found in the dry LC1 with only 20 in the wet LC2 (Table 3). The same trend was observed for seeded and volunteer taxa with the species richness being higher in the dry site (LC1) compared to the wet site (LC2). Regardless, only $46 \%$ of the originally seeded taxa were found with the rest of the seeded taxa not being evident in our study. This may be due to the drought conditions (i.e., moderate and abnormally dry) (National Drought Mitigation Center 2008), under which the wetland seed mix may have partially failed to germinate during the growing season. It seems the drought condition for the first growing season allowed drought tolerant, volunteer plants to become established in the mitigation wetland (Table 2). There were several FACU and UPL species found among the volunteers established (Table 2). These species most likely are expected to be out-competed by more obligate wetland species (i.e., < FAC) when precipitation levels are normal and the site is wetter. The percent cover of vegetation ranged overall between $14-91 \%$ per plot (Table 3). Percent cover of overall, seeded, and volunteer taxa in disked plots was higher than or comparable to those of non-disked plots (Table 3).

Moser et al. (2007) reported a similarly positive effect of disking on species richness and percent cover, but the 

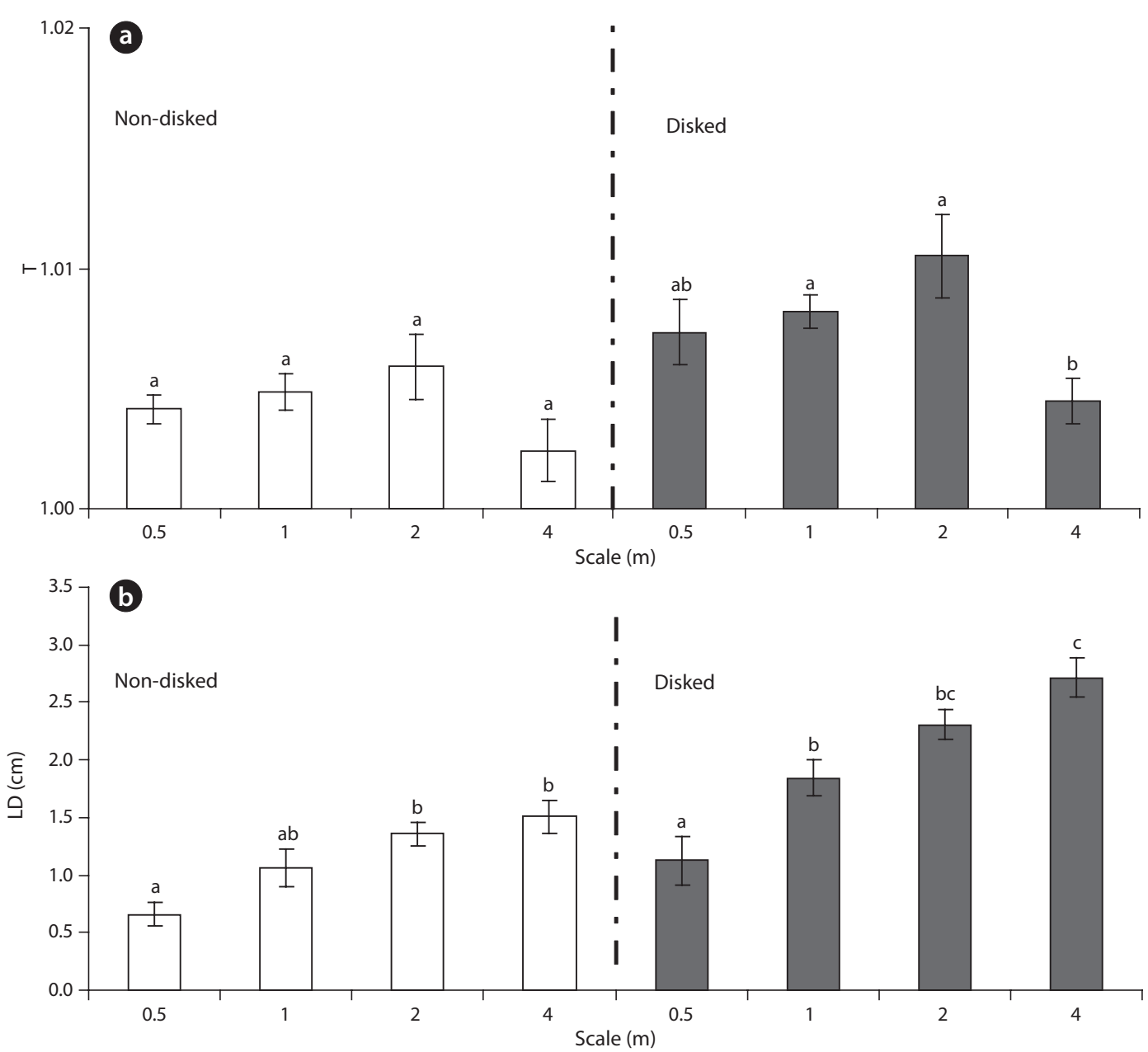

Fig. 3. Microtopography measures (i.e., roughness and relief) for each transect scale in non-disked and disked plots in Loudoun County mitigation wetland: (a) tortuosity (T); $N=6$ per scale for non-disked plots, $N=6$ per scale for disked plots, except $0.5 \mathrm{~m}$ transect, where $N=5$; (b) limiting elevation difference (LD) across different scales; $N=6$ per scale for non-disked plots and $N=6$ per scale for disked plots, except $0.5 \mathrm{~m}$ scale, where $N=5$. For both $T$ and $L D$, all values are mean \pm standard error. Significant differences in T and LD among scales are indicated by different letters above bars (Fisher's least significant difference comparison of means) at $a=0.05$.

Table 1. Microtopographic indices calculated at each circular transect scale for two created wetland sites, LC1 and LC2, under two different disking treatments

\begin{tabular}{|c|c|c|c|c|c|c|c|c|c|c|c|c|c|}
\hline & \multirow[b]{3}{*}{ Scale (m) } & \multicolumn{6}{|c|}{ Non-disked } & \multicolumn{6}{|c|}{ Disked } \\
\hline & & \multicolumn{3}{|c|}{ LC1 (dry) } & \multicolumn{3}{|c|}{ LC2 (wet) } & \multicolumn{3}{|c|}{ LC1 (dry) } & \multicolumn{3}{|c|}{ LC2 (wet) } \\
\hline & & A & B & $\mathrm{C}$ & D & E & $F$ & AA & BB & $\mathrm{CC}$ & DD & EE & FF \\
\hline \multirow[t]{4}{*}{$\mathrm{T}$} & 0.5 & 1.002 & 1.001 & 1.010 & 1.005 & 1.003 & 1.004 & 1.006 & 1.008 & 1.014 & 1.004 & 1.024 & 1.005 \\
\hline & 1 & 1.003 & 1.001 & 1.011 & 1.004 & 1.005 & 1.006 & 1.008 & 1.006 & 1.013 & 1.008 & 1.007 & 1.007 \\
\hline & 2 & 1.002 & 1.002 & 1.011 & 1.007 & 1.006 & 1.007 & 1.015 & 1.009 & 1.016 & 1.005 & 1.010 & 1.009 \\
\hline & 4 & 1.001 & 1.001 & 1.006 & 1.001 & 1.003 & 1.002 & 1.006 & 1.003 & 1.006 & 1.005 & 1.003 & 1.004 \\
\hline \multirow[t]{4}{*}{ LD } & 0.5 & 0.447 & 0.362 & 1.007 & 0.707 & 0.591 & 0.821 & 1.065 & 1.035 & 1.591 & 0.814 & 1.880 & 1.131 \\
\hline & 1 & 1.404 & 0.467 & 1.373 & 1.204 & 1.005 & 0.934 & 2.211 & 1.920 & 2.433 & 1.378 & 1.654 & 1.474 \\
\hline & 2 & 0.818 & 0.900 & 2.215 & 1.499 & 1.157 & 1.547 & 3.268 & 3.046 & 2.109 & 1.640 & 1.686 & 2.089 \\
\hline & 4 & 1.018 & 1.277 & 2.104 & 1.792 & 1.507 & 1.344 & 3.035 & 3.145 & 1.983 & 3.765 & 1.782 & 2.606 \\
\hline
\end{tabular}


Table 2. Plant species observed in Loudoun County mitigation wetland (LC) in 2007 and their wetland indicator status and coefficient of conservatism scores

\begin{tabular}{|c|c|c|c|c|}
\hline \multirow{2}{*}{ Scientific name } & \multirow{2}{*}{ Common name } & \multirow{2}{*}{ Wetland indicator status ${ }^{\ddagger}$} & \multicolumn{2}{|c|}{$\begin{array}{c}\text { No. of plots where indicator status } \\
\text { species is present }\end{array}$} \\
\hline & & & Non-disked & Disked \\
\hline \multicolumn{5}{|l|}{ Seeded taxa } \\
\hline Asclepias incarnata $\mathrm{L}$. & Swamp milkweed & OBL & 0 & 1 \\
\hline Bidens polylepis & Bearded beggarticks & FACW & 0 & 1 \\
\hline Carex comosa & Longhair sedge & OBL & 0 & 2 \\
\hline Carex sp. & Sedge & FAC & 4 & 4 \\
\hline Elymus virginicus $\mathrm{L}$. & Virginia wildrye & FACW & 2 & 6 \\
\hline Eupatorium perfoliatum $\mathrm{L}$. & Common boneset & FACW & 1 & 0 \\
\hline Juncus effusus L. & Common rush & FACW & 1 & 2 \\
\hline Lolium multiflorum Lam. & Italian ryegrass & FACU & 4 & 3 \\
\hline Panicum virgatum $\mathrm{L}$. & Switchgrass & FAC & 1 & 3 \\
\hline Polygonum & Pennsylvania & FACW & 2 & 1 \\
\hline pensylvanicum $\mathrm{L}$. & smartweed & & & \\
\hline Verbena hastata & Swamp verbena & FACW & 2 & 2 \\
\hline Vernonia gigantea (Walt.) Trel. & Giant ironweed & FAC & 0 & 1 \\
\hline \multicolumn{5}{|l|}{ Volunteer taxa } \\
\hline Acalypha rhomboidea & Common threeseed & FACU & 2 & 2 \\
\hline Ambrosia artemisiifolia & Aannual ragweed & FACU & 2 & 3 \\
\hline Arthraxon hispidus* & Small carpgrass & NI & 0 & 1 \\
\hline Boehmeria cylindrica & Smallspike false nettle & FACW & 1 & 2 \\
\hline Cirsium muticum & Swamp thistle & OBL & 0 & 1 \\
\hline Corydalis sempervirens & Rock harlequin & NI & 1 & 2 \\
\hline Cyperus strigosus & Strawcolored flatsedge & FACW & 0 & 1 \\
\hline Digitaria sanguinalis & Hairy crabgrass & FACU & 0 & 1 \\
\hline Diodia virginiana & Virginia buttonweed & FACW & 0 & 1 \\
\hline Echinochloa crus-galli & Barnyard grass & FACW & 2 & 3 \\
\hline Eleocharis obtusa & Blunt spikerush & OBL & 1 & 2 \\
\hline Erechtites hieraciifolia & American burnweed & FACU & 0 & 1 \\
\hline Galium tinctorium & Stiff marsh bedstraw & OBL & 0 & 1 \\
\hline Juncus tenuis & Poverty rush & FAC & 6 & 6 \\
\hline Lespedeza violacea & Violet Lespedeza & NI & 0 & 1 \\
\hline Ludwigia palustris & Marsh seedbox & OBL & 1 & 1 \\
\hline Oxalis stricta & Common yellow oxalis & UPL & 2 & 6 \\
\hline Persicaria perfoliata & Asiatic tearthumb & FAC & 0 & 1 \\
\hline Phleum pratense* & Timothy & FACU & 0 & 3 \\
\hline Plantago major & Common plantain & FACU & 1 & 2 \\
\hline Polygonum hydropiper & Marshpepper knotweed & OBL & 2 & 5 \\
\hline Polygonum persicaria ${ }^{\dagger}$ & Spotted ladysthumb & FACW & 2 & 3 \\
\hline Pycnanthemum tenuifolium & Narrowleaf mountainmint & FACW & 1 & 2 \\
\hline Rumex crispus" & Curly dock & FACU & 1 & 2 \\
\hline Scirpus cyperinus & Woolgrass & FACW & 1 & 1 \\
\hline Toxicodendron radicans & Eastern poison ivy & FAC & 0 & 1 \\
\hline Typha angustifolia & Narrow leaf cattail & OBL & 0 & 1 \\
\hline Verbascum thapsus & Common mullein & NI & 0 & 1 \\
\hline Verbena urticifolia & White vervain & FACU & 1 & 2 \\
\hline
\end{tabular}

OBL, obligate wetland species; FACW, facultative wetland species; FACU, facultative upland; FAC, facultative species; UPL, obligate upland; NI, no wetland indicator status assigned for Region 1.

"Moderately invasive species.

${ }^{\dagger}$ Highly invasive species. Invasiveness was determined by using invasive alien plant species of Virginia list prepared by the Department of Conservation and Recreation, Virginia.

"Wetland indicator status for the Northeast Region (Region 1) (Reed 1988). 


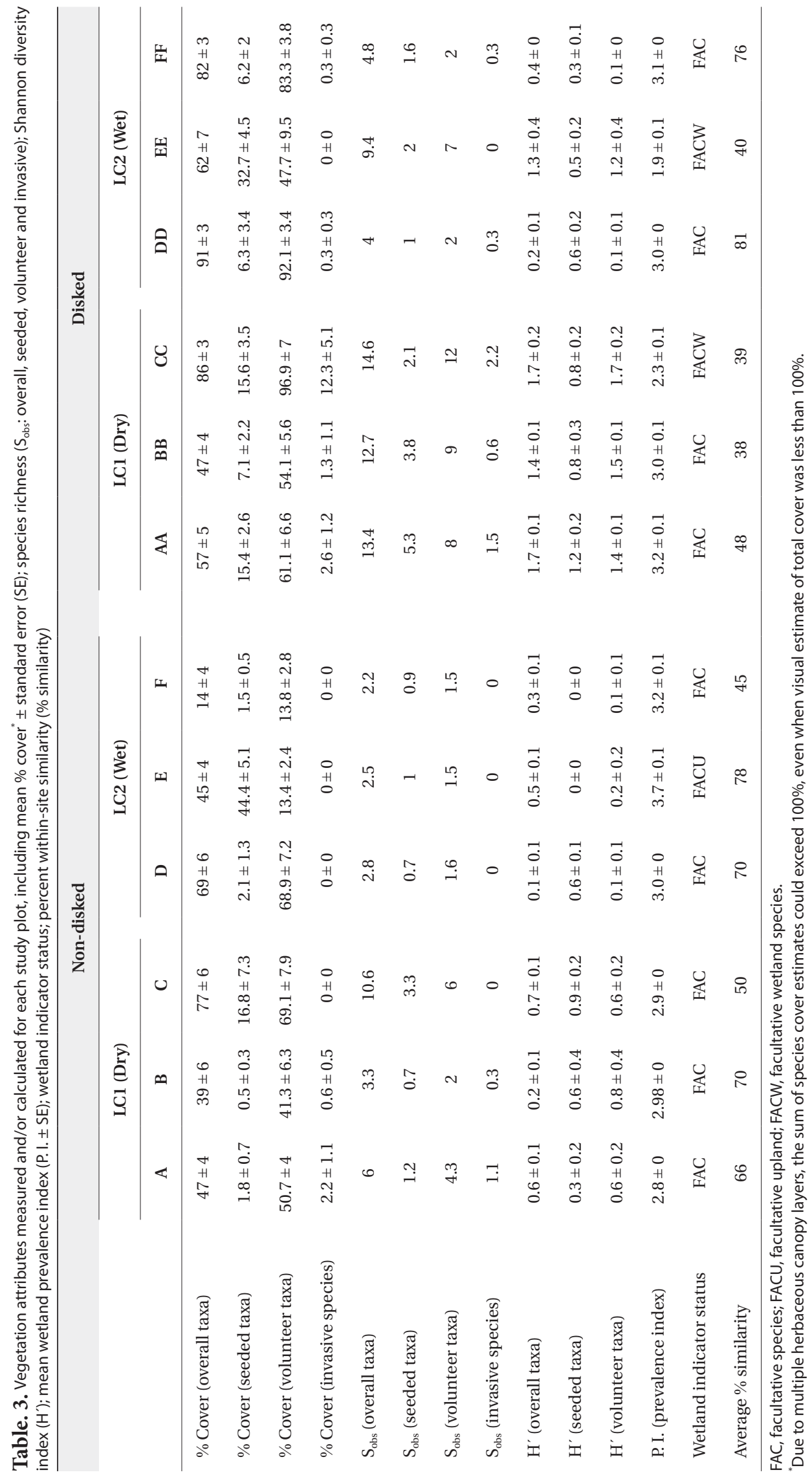


result was partially masked by the ages of created wetlands investigated in that study. As a created wetland ages with further development of vegetation communities microtopography may change due to factors other than initial disking, especially biogenically by tussockforming wetland plants (Werner and Zedler 2002). Since our study focused solely on the first growing season plant community development in a newly created wetland our results clearly showed the positive effects of disking as a creation method and/or a design element on vegetation establishment.

\section{Invasive species}

It has been shown that invasive species can change or control the structure and function of wetlands (Galatowitsch et al. 1999, Zelder and Kercher 2004), thus a careful monitoring of invasive species is important, especially in early plant community development in created wetlands. In our study, there were many transects (plots) with no invasive species found. Only few plots (i.e., 1-3) (Table 2) had invasive species making the data highly skewed for statistical comparisons between different site conditions. The number and the percent cover of invasive species found per plot ranged from 0 to 2.2 and from 0 up to $12.3 \%$, respectively (Table 3 ). The highest percent cover (i.e., $12.3 \%$ ) was observed in one plot that was dry and disked (i.e., plot CC) (Table 3) with all other plots being under $3 \%$, showing that dry condition facilitated natural colonization of invasive species that were mostly FACU. The percentage of invasive species contributing to overall species richness was fairly small in both disked plots $(8.3 \%)$ and non-disked plots (5\%) as well as in dry plots $(9.4 \%)$ and wet plots (2.3\%) (Table 3), all under the $10 \%$ criterion for mitigation success criteria.

\section{Shannon-Weiner diversity $\left(\mathrm{H}^{\prime}\right)$}

Shannon diversity $\left(\mathrm{H}^{\prime}\right)$ of overall taxa was $69 \%$ and $57 \%$ higher in disked plots than in non-disked in LC1 and LC2, respectively (Table 3). H's of seeded and volunteer taxa were $49 \%$ and $62 \%$ higher, respectively, in disked plots than those in non-disked plots (Table 3). H's of seeded and volunteer taxa were $65 \%$ and $72 \%$ higher, respectively, in the dry LC1 than those in the wet LC2 (Table 3). Microtopographic heterogeneity is a controlling factor on the diversity of vegetation (Titus 1990, Vivian-Smith 1997). The result of this study proves that the previous finding applies to artificially-induced microtopographic heterogeneity and its influence on the diversity of vegetation community. Overall, H' values were comparable with those found in a created wetland bank by the same builder in the vicinity of LC (Moser et al. 2007).

\section{Wetland prevalence index (P. I.)}

Most of the study plots except one non-disked plot (FACU) (Table 3) were dominated by wetland plants ( $\leq$ FAC) (Table 3). P. I. was not significantly different either between disked ( 2.9) and non-disked plots (3.1) or between LC1 (dry, 2.9) and LC2 (wet, 3.0) sites (Table 4), showing no specific effects of either disking or hydrologic regime. Microtopography indices (i.e., $\mathrm{T}$ and $\mathrm{LD}$ ) calculated were significantly higher in disked plots than in non-disked plots (see Section Microtopography), but it does not seem to affect wetland indicator status of vegetation community established in the first year. However, there were more FACW and FAC species found in disked plots than in non-disked plots overall (Table 3), suggesting that microtopography induced by disking may have contributed to better supporting wetland plant establishment in the first year, which was similar to what was found in older created wetlands in the same region (Moser et al. 2007). P. I. was significantly negatively correlated with $\mathrm{T}$, indicating the more rough the surface the lower the P. I. (i.e., more of a wetland plant status), however, was not correlated with LD. Even the clear difference in hydrologic regime between the dry LC1 and wet LC2 observed did not lead to any significant difference in plotlevel wetland indicator status of vegetation (Table 4) in this study.

\section{Within plot plant-taxa similarity (\%)}

Disked plots in LC1 consistently showed lower within plot similarity than non-disked plots in both LC1 and LC2, indicating that disking may have contributed to enhance plant taxa heterogeneity in those plots as reflected in their H's (Table 3). There was, though, no notable difference in within plot similarity between LC1 and LC2 (i.e., by hydrologic regime). Disking during the construction may assist to prevent occupancy of generalist species in the early development of vegetation community.

\section{Effects of hydrologic and microtopographic designs on vegetation community establishment}

Results of MANOVA revealed no scale effect (Pillai's Trace $\left.=0.885, F_{30,75}=1.046, P=0.424\right)$. The effects of disking (Pillai's Trace $=0.864, F_{10,23}=14.559, P<0.001$ ) and hydrologic regime (Pillai's Trace $=0.831, F_{10,23}=11.27, P$ $<0.001$ ), however, were significant on the combined dependent variables of vegetation attributes. Therefore, we used separate ANOVAs to analyze the effects of disking and hydrologic regime only, for each of the vegetation re- 
Table 4. The result of ANOVA for plant percent cover, species richness $\left(\mathrm{S}_{\mathrm{obs}}\right)$, Shannon's diversity $\left(\mathrm{H}^{\prime}\right)$, and prevalence index (P. I.) as affected by disking (i.e., disked vs. non-disked) and hydrologic regime (i.e., dry vs. wet)

\begin{tabular}{|c|c|c|c|c|}
\hline Source of variation & Df & MS & $F$ & $P$ \\
\hline \multicolumn{5}{|l|}{ Percent cover (overall taxa) } \\
\hline Disking & 1,32 & 3.763 & 9.621 & 0.004 \\
\hline Hydrologic regime & 1,32 & 0.049 & 0.126 & 0.725 \\
\hline \multicolumn{5}{|l|}{ Percent cover (seeded taxa) } \\
\hline Disking & 1,32 & 4.296 & 0.010 & 0.922 \\
\hline Hydrologic regime & 1,32 & 112.180 & 0.255 & 0.617 \\
\hline \multicolumn{5}{|l|}{ Percent cover (volunteer taxa) } \\
\hline Disking & 1,32 & 71.294 & 14.080 & 0.001 \\
\hline Hydrologic regime & 1,32 & 11.430 & 2.257 & 0.143 \\
\hline \multicolumn{5}{|l|}{$\mathrm{S}_{\mathrm{obs}}$ (overall taxa) } \\
\hline Disking & 1,32 & 7.848 & 40.331 & $<0.001$ \\
\hline Hydrologic regime & 1,32 & 7.760 & 39.861 & $<0.001$ \\
\hline \multicolumn{5}{|l|}{$\mathrm{S}_{\mathrm{obs}}$ (seeded taxa) } \\
\hline Disking & 1,32 & 9.865 & 16.474 & $<0.001$ \\
\hline Hydrologic regime & 1,32 & 6.542 & 10.925 & 0.002 \\
\hline \multicolumn{5}{|l|}{$\mathrm{S}_{\mathrm{obs}}($ volunteer taxa) } \\
\hline Disking & 1,32 & 74.45 & 42.910 & $<0.001$ \\
\hline Hydrologic regime & 1,32 & 87.858 & 50.637 & $<0.001$ \\
\hline Disking" Hydrologic regime & 1,32 & 18.025 & 10.908 & 0.002 \\
\hline \multicolumn{5}{|l|}{$\mathrm{H}^{\prime}$ (overall taxa) } \\
\hline Disking & 1,32 & 6.315 & 37.227 & $<0.001$ \\
\hline Hydrologic regime & 1,32 & 4.471 & 26.360 & $<0.001$ \\
\hline Disking" Hydrologic regime & 1,32 & 1.729 & 10.193 & 0.003 \\
\hline \multicolumn{5}{|l|}{$\mathrm{H}^{\prime}$ (seeded taxa) } \\
\hline Disking & 1,32 & 1.504 & 11.578 & 0.002 \\
\hline Hydrologic regime & 1,32 & 2.903 & 22.339 & $<0.001$ \\
\hline \multicolumn{5}{|l|}{$\mathrm{H}^{\prime}$ (volunteer taxa) } \\
\hline Disking & 1,32 & 4.641 & 18.065 & $<0.001$ \\
\hline Hydrologic regime & 1,32 & 7.536 & 29.335 & $<0.001$ \\
\hline \multicolumn{5}{|l|}{ P. I. (overall taxa) } \\
\hline Disking & 1,32 & 0.112 & 0.164 & 0.992 \\
\hline Hydrologic regime & 1,32 & 1.068 & 1.561 & 0.221 \\
\hline
\end{tabular}

No spatial scale effects were observed in any of vegetation attributed measured. Interaction terms appears only when significant at $a=0.05$. 
sponse variables as reported in Table 4 . The overall and volunteer taxa percent covers were significantly higher in disked plots than in non-disked plots (Table 4), showing a positive effect of disking practice on the first-year plant establishment in a created mitigation wetland. However, the percent cover of vegetation did not differ by hydrologic regime between L1 (dry) and L2 (wet) (Table 4). The percent cover of overall taxa were significantly correlated with both $\mathrm{T}$ and $\mathrm{LD}$ (Table 5) in a positive manner, indicating induced microtopography enhanced the development in vegetation coverage in the newly created wetland. T was strongly correlated with seeded taxa development whereas LD was correlated with volunteer taxa (Table 5).

The species richness for each of overall, seeded, and volunteer taxa was significantly influenced by both disking and hydrologic regime (Table 4). The correlation between the species richness and two microtopography indices (i.e., $\mathrm{T}$ and $\mathrm{LD}$ ) was highly significant (Table 5). Disked plots showed 55\% higher overall taxon richness and $53 \%$ higher seeded taxon richness than those of nondisked plots, and the dry LC1 showed 55\% higher overall taxon richness and $45 \%$ seeded taxon richness than those of the wet LC2 (Table 3). There was no significant interaction between disking and hydrologic regime, except for volunteer taxa (Table 4). The volunteer taxon richness was more pronounced in the disked, dry plots, being $59 \%$ higher than in non-disked, dry plots (Table 3).

$\mathrm{H}^{\prime}$ for overall, seeded, and volunteer species was affected significantly by disking and hydrologic regime, and there was also a two-way interaction between disking and hydrologic regime for overall taxa (Table 4). $\mathrm{H}^{\prime}$ was higher in disked than non-disked plots, showing the positive effect of disking on establishing the diversity of vegetation community. Hydrologic regime also significantly influenced the vegetation development during the first growing season (Table 4), promoting the diversity in a relatively dry condition. It seems that the dry condition in LC1 has facilitated the colonization of volunteer species. The species diversity of vegetation was highest in dry, disked plots (Table 4). There was a significant correlation between the $\mathrm{H}^{\prime}$ of vegetation of all categories (i.e., overall, seeded, and volunteer taxa) and LD (Table 5). H's of overall taxa was significantly correlated with $\mathrm{T}$ whereas $\mathrm{H}$ 's of seeded and volunteer taxa were not (Table 5). The result was consistent with Moser et al. (2007), proving the positive effect of microtopography on vegetation development.

The positive effect of disking was clear in this study due to the specific treatment design of disking. Microtopographic variation was also found strongly correlated with the distribution and vigor of individual plant species and communities in wetlands (Watt 1947, Schlesinger 1978). However, it is not clear how long the positive effect of disking-induced microtopography as part of construction of mitigation bank will last. The positive effects of disking might fade away over time, but some studies suggested that biogenic microtopographic features such as plantoriented mounds and hummocks usually develop as plant community mature over several growing seasons, contributing to habit diversity (Werner and Zedler 2002, Peach and Zedler 2006). Further investigation is needed on how mechanically-induced heterogeneity (i.e., by disking) may relate to microtopographic features that are being biogenically developed along with plant community maturation in created wetlands.

\section{CONCLUSION}

Understanding design elements of a newly created mitigation wetland and their influence on vegetation development is important to ensuring the success of mitigation. This study examined two design elements microtopography and hydrologic regime - and their effects on the first year vegetation development pattern of a newly created mitigation wetland. Created mitigation wetlands often lack microtopography due to use of heavy machinery for grading during construction process, which often lead to a vegetatively monotypic system with

Table 5. Pearson correlations between microtopographic indices (i.e., $T=$ tortuosity; $L D=$ limiting elevation difference) and vegetation attributes (i.e., percent cover, species richness $\left[S_{o b s}\right]$, Shannon diversity $\left[H^{\prime}\right]$, and prevalence index [P. I.])

\begin{tabular}{|c|c|c|c|c|c|c|c|c|c|c|}
\hline & \multicolumn{3}{|c|}{ Percent cover ( $r$-value) } & \multicolumn{3}{|c|}{$\mathrm{S}_{\text {obs }}(r$-value $)$} & \multicolumn{3}{|c|}{$\mathrm{H}^{\prime}(r$-value $)$} & \multirow{2}{*}{$\frac{\text { P. I. ( } r \text {-value) }}{\text { Overall }}$} \\
\hline & Overall & Seeded & Volunteer & Overall & Seeded & Volunteer & Overall & Seeded & Volunteer & \\
\hline $\mathrm{T}$ & $\underline{0.33}$ & 0.45 & 0.15 & 0.47 & 0.40 & 0.43 & 0.42 & 0.19 & 0.28 & -0.48 \\
\hline LD & $\underline{0.30}$ & -0.01 & $\underline{0.36}$ & 0.44 & 0.38 & 0.39 & 0.45 & 0.59 & 0.38 & -0.25 \\
\hline
\end{tabular}

Values in boldface indicate that correlation is significant at the 0.01 level and values underlined indicate that correlation is significant at the 0.05 level. 
few species. This study found that design elements such as hydrology and disking-induced microtopography significantly influenced the vegetation community in a mitigation wetland in the first growing season. Our study showed that disking clearly enhanced microtopography in created wetlands and the increased microtopography positively influenced percent cover, species richness, and diversity of wetland vegetation. Disking-induced microtopography also contributed to preventing the dominance of generalist species by lowering within-group similarity of vegetation community and encouraging the colonization of more volunteer taxa in a created mitigation wetland. Hydrologic regime characterized by longer periods of unsaturated or low water table levels was also associated with higher species richness and diversity. Wetland engineers and managers are recommended to incorporate disking as part of construction of wetlands with a careful management of hydrologic regime for successful vegetation establishment and development in a newly created wetland.

\section{ACKNOWLEDGMENTS}

The research was sponsored by National Competitive Grant Program (06HQGR0189) from National Institute of Water Resources, United States of Geological Survey, which supported research assistants for their wages. Reviews of the manuscript by Laura Giese and one anonymous reviewer are appreciated. Thanks go to Lisa Williams for her assistance in vegetation survey and identification. For the permission for site access, plot establishment and well data, I thank to Wetland Studies and Solutions, Inc.

\section{LITERATURE CITED}

Ahn C, White DC, Sparks RE. 2004. Moist-soil plants as ecohydrologic indicators for recovering the flood pulse in the Illinois River. Restor Ecol 12: 207-213.

Atkinson RB, Perry JE, Cairns J Jr. 2005. Vegetation communities of 20-year-old created depressional wetlands. Wetl Ecol Manag 13: 469-478.

Baer SG, Collins SL, Blair JM, Knapp AK, Fiedler AK. 2005. Soil heterogeneity effects on tallgrass prairie community heterogeneity: an application of ecological theory to restoration ecology. Restor Ecol 13: 413-424.

Breaux A, Serefiddin F. 1999. Validity of performance criteria and a tentative model for regulatory use in compensa- tory wetland mitigation permitting. Environ Manag 24: 327-336.

Bruland GL, Richardson CJ. 2005. Hydrologic, edaphic, and vegetative responses to microtopographic reestablishment in a restored wetland. Restor Ecol 13: 515-523.

Campbell DA, Cole CA, Brooks RP. 2002. A comparison of created and natural wetlands in Pennsylvania, USA. Wetl Ecol Manag 10: 41-49.

Colwell RK. 2006. EstimateS: statistical estimation of species richness and shared species from samples. Software and user's guide, version 8. http://viceroy.eeb.uconn.edu/ estimates. Accessed 20 May 2010.

Cronk JK, Fennessy MS. 2001. Wetland Plants: Biology and Ecology. CRC Press, Boca Raton, FL.

Dwire KA, Kauffman JB, Baham JE. 2006. Plant species distribution in relation to water-table depth and soil redox potential in Montane riparian meadows. Wetlands 26: 131-146.

Federal Interagency Committee for Wetland Delineation. 1989. Federal Manual for Identifying and Delineating Jurisdictional Wetlands. U.S. Army Corps of Engineers, U.S. Environmental Protection Agency, U.S. Fish and Wildlife Service, U.S.D.A. Soil Conservation Service, Washington, DC.

Galatowitsch SM, van der Valk AG. 1996. Vegetation and environmental conditions in recently restored wetlands in the prairie pothole region of the USA. Vegetatio 126: 89-99.

Galatowitsch SM, Anderson NO, Ascher PD. 1999. Invasiveness in wetland plants in temperate North America. Wetlands 19: 733-755.

Hamrick JL, Lee JM. 1987. Effect of soil surface topography and litter cover on the germination, survival, and growth of Musk Thistle (Carduus nutans). Am J Bot 74: 451-457.

Heddinghause TR, Sabol P. 1991. A review of the palmer drought severity index and where do we go from here? Proceedings of the $7^{\text {th }}$ Conference on Applied Climatology, 1991 Sep 10-13, Salt Lake City, UT. American Meteorological Society, Boston, MA.

Jerling L. 1981. Effects of microtopography on the summer survival of Plantago maritima seedlings. Holarct Ecol 4: 120-126.

Kamphorst EC, Jetten V, Guérif J, Pitkänen J, Iversen BV, Douglas JT, Paz A. 2000. Predicting depressional storage from soil surface roughness. Soil Sci Soc Am J 64: 17491758.

Linden DR, Van Doren DM. 1986. Parameters for characterizing tillage-induced soil surface roughness. Soil Sci Soc Am J 50: 1560-1565.

Miller SJ, Wardrop DH. 2006. Adapting the floristic qual- 
ity assessment index to indicate anthropogenic disturbance in central Pennsylvania wetlands. Ecol Indicators 6: 313-326.

Morzaria-Luna H, Callaway JC, Sullivan G, Zedler JB. 2004. Relationship between topographic heterogeneity and vegetation patterns in a Californian salt marsh. J Veg Sci 15: 523-530.

Moser K, Ahn C, Noe G. 2007. Characterization of microtopography and its influence on vegetation patterns in created wetlands. Wetlands 27: 1081-1097.

National Drought Mitigation Center. 2008. U.S. drought monitor. http://drought.unl.edu/dm/archive.html. Accessed 20 August 2008.

National Research Council. 2001. Compensating For Wetland Losses under the Clean Water Act. National Academy Press, Washington, DC.

Peach M, Zedler JB. 2006. How tussocks structure sedge meadow vegetation. Wetlands 26: 322-335.

Pepin AL. 2000. Correction of indicator status for Echinochloa crusgalli (Barnyard Grass). Virginia Association of Wetland Professionals Update 7: 4-5.

PRIMER-E Ltd. 2006. PRIMER v6.1. PRIMER-E Ltd., Plymouth.

Reed PB. 1988. National Wetlands Inventory, U.S. Fish and Wildlife Service, U.S. National Interagency Review Panel, and U.S. Regional Interagency Review Panel: Northeast (Region 1). 1988. National list of plant species that occur in wetlands. Northeast (Region 1). U.S. Department of the Interior, Fish and Wildlife Service, Research and Development, Washington, DC.

Schlesinger WH. 1978. On the relative dominance of shrubs in Okefenokee Swamp. Am Nat 112: 949-954.

Schupp EW. 1995. Seed-seedling conflicts, habitat choice, and patterns of plant recruitment. Am J Bot 82: 399-409.

Smith M, Capelle J. 1992. Effects of soil surface microtopography and litter cover on germination, growth and biomass production of Chicory (Cichorium intybus L.). Am Midl Nat 128: 246-253.

Spieles DJ. 2005. Vegetation development in created, restored, and enhanced mitigation wetland banks of the United States. Wetlands 25: 51-63.

SPSS. 2006. SPSS version 15.0. SPSS Inc., Chicago, IL.

Stolt MH, Genthner MH, Daniels WL, Groover VA, Nagle S, Haering KC. 2000. Comparison of soil and other en- vironmental conditions in constructed and adjacent palustrine reference wetlands. Wetlands 20: 671-683.

Tabachnick BG, Fidell LS. 2001. Using Multivariate Statistics. Allyn and Bacon, Boston, MA.

Tiner RW. 1988. Field Guide to Nontidal Wetland Identification. Maryland Department of Natural Resources, Water Resources Administration, U.S. Department of the Interior, Fish and Wildlife Service, Annapolis, MD \& Newton Corner, MA.

Titus HJ. 1990. Microtopography and woody plant regeneration in a hardwood floodplain swamp in Florida. Bull Torrey Bot Club 117: 429-437.

Tweedy KL, Scherrer E, Evans RO, Shear TH. 2001. Influence of microtopography on restored hydrology and other wetland functions. 2001 American Society of Agricultural Engineers Annual International Meeting, Jul 30-Aug 1, Sacramento, CA. American Society of Agricultural Engineers, St. Joseph, MI.

van der Valk AG. 1981. Succession in wetlands: a Gleasonian approach. Ecology 62: 688-696.

van der Valk AG, Davis CB. 1978. The role of seed banks in the vegetation dynamics of prairie glacial marshes. Ecology 59: 322-335.

Vivian-Smith G. 1997. Microtopographic heterogeneity and floristic diversity in experimental wetland communities. J Ecol 85: 71-82.

Watt AS. 1947. Pattern and process in the plant community. J Ecol 35: 1-22.

Wentworth TR, Johnson GP, Kologiski RL. 1988. Designation of wetlands by weighted averages of vegetation data: a preliminary evaluation. Water Resour Bull 24: 389-396.

Werner KJ, Zedler JB. 2002. How sedge meadow soils, microtopography, and vegetation respond to sedimentation. Wetlands 22: 451-466.

Whittecar GR, Daniels WL. 1999. Use of hydrogeomorphic concepts to design created wetlands in southeastern Virginia. Geomorphology 31: 355-371.

Zedler JB, Callaway JC. 1999. Tracking wetland restoration: do mitigation sites follow desired trajectories? Restor Ecol 7: 69-73.

Zedler JB, Kercher S. 2004. Causes and consequences of invasive plants in wetlands: Opportunities, opportunists, and outcomes. Crit Rev Plant Sci 23: 431-452. 